\title{
Research on Indoor Thermal Environment of Residential Building in
}

\section{Yubei}

\author{
XIAO LI LI ${ }^{1, a}$, HAI YAN YAN ${ }^{2, b}$ and WEN FANG WANG ${ }^{1, c}$ \\ ${ }^{1}$ Department of Architecture, Xian University of Architecture \& Technology, Xian, Shanxi, China; \\ ${ }^{2}$ Department of Architectural \& Art design, Henan Polytechnic University, Jiaozuo, Henan, China \\ alixiaoli1126@163.com, byhy@hpu.edu.cn,, 176025081@qq.com
}

\begin{abstract}
Keywords: Adobe house; Brick dwelling; Temperature; Relative Humidity; Indoor Thermal Environment

Abstract. A village of Yubei, the typical area of north of Henan Province was selected. A field study was conducted in the traditional adobe house and newly built brick house, indoor and outdoor temperature, relative humidity and other indoor thermal environment parameters were obtained in winter. The results indicated that the indoor thermal environment in new and old folk houses were all lower than the local residential building thermal environment standard. Test data show that open the north door and one font design is the main reason leading to the adobe building indoor thermal environment is poor, and brick house around the main room layout features of "disposition" design is the main reason to maintain its good indoor thermal environment. The results provided the basis for the improvement of indoor thermal environment and the design of new residential buildings in this area, which provided the basis for the energy saving and sustainable development of rural residential buildings.
\end{abstract}

\section{Introduction}

With the promotion of the beautiful countryside construction, many designs for new eco-rural housing have been tried, in which the passive design becomes the consent method of the low carbon and low technology energy-saving. The issue of the indoor thermal environment of residential buildings has been paid much attention by more and more researchers. The northern part of Henan province, located in the North of the Yellow River, is the transition region of the Taihang Mountain to the Northern Henan plain area, with the features of the transitional climate of both the cold North and damp-heat South: dry and windy in spring, hot and rainy in summer, comfortable and fresh in autumn, and cold and snow-less in winter. For the full understanding of the indoor thermal environment of residential buildings in the transition climate district, the paper researches on the village, located in Yubei area. Through the survey on the traditional adobe houses and new brick mixed houses, as well as the test and compared research of the indoor thermal environment, this thesis analyzes the relationship between the built technology, including the building form, material, structure and the deal of details, and the indoor thermal environment or even the local geographical climate to guide the design and construction of the local modern houses.

\section{Methods}

Test subject. The typical area of North Henan -- A Village, Boai County of Jiaozuo City is being tested. The layout of The tested traditional adobe house is a rectangle. It is a civil architecture which faces south. It is three rooms wide and the living room is 6.2 meters. Each living room is 2.5 long and 4.2 wide. The outer wall, made of rammed earth, is $400 \mathrm{~mm}$ thick. It is covered with grass and mud. The inner wall is $240 \mathrm{~mm}$ thick and is partly covered with paperhanging production. The floor in the room is made with rammed earth and clay bricks are on the top. The passage in the courtyard is lined with old bricks pavements. The sloping roof is made of bearing structure and roof. The roof is made up with $300 \mathrm{~mm}$ grass and mud. Under the roof, there is a wooden ceiling, covered with paperhanging 
construction. There are wooden single-layer glass windows. The thermal performance and temperature measurement spot is shown in Fig. 1(a)

The layout of tested brick house is a square. It is a two-story brick construction which is built in 2003. It also faces south, with 16meters as every side and 3.9meters as each height. The outer wall is made with $240 \mathrm{~mm}$ solid clay, and decorated with dry dash method. There is $120 \mathrm{~mm}$ brick wall in the inner wall. It uses plaster on the surface. It laid the ceramic tile on the ground, outside the room, it treats with cement mortar hardening. The roof construction is the $120 \mathrm{~mm}$ thick slab flat and it doesn't take insulation and heat insulation. The window is ordinary aluminum single-layer glass. The second floor faces south. The thermal performance and temperature measurement spot is shown in Fig. 1(b)

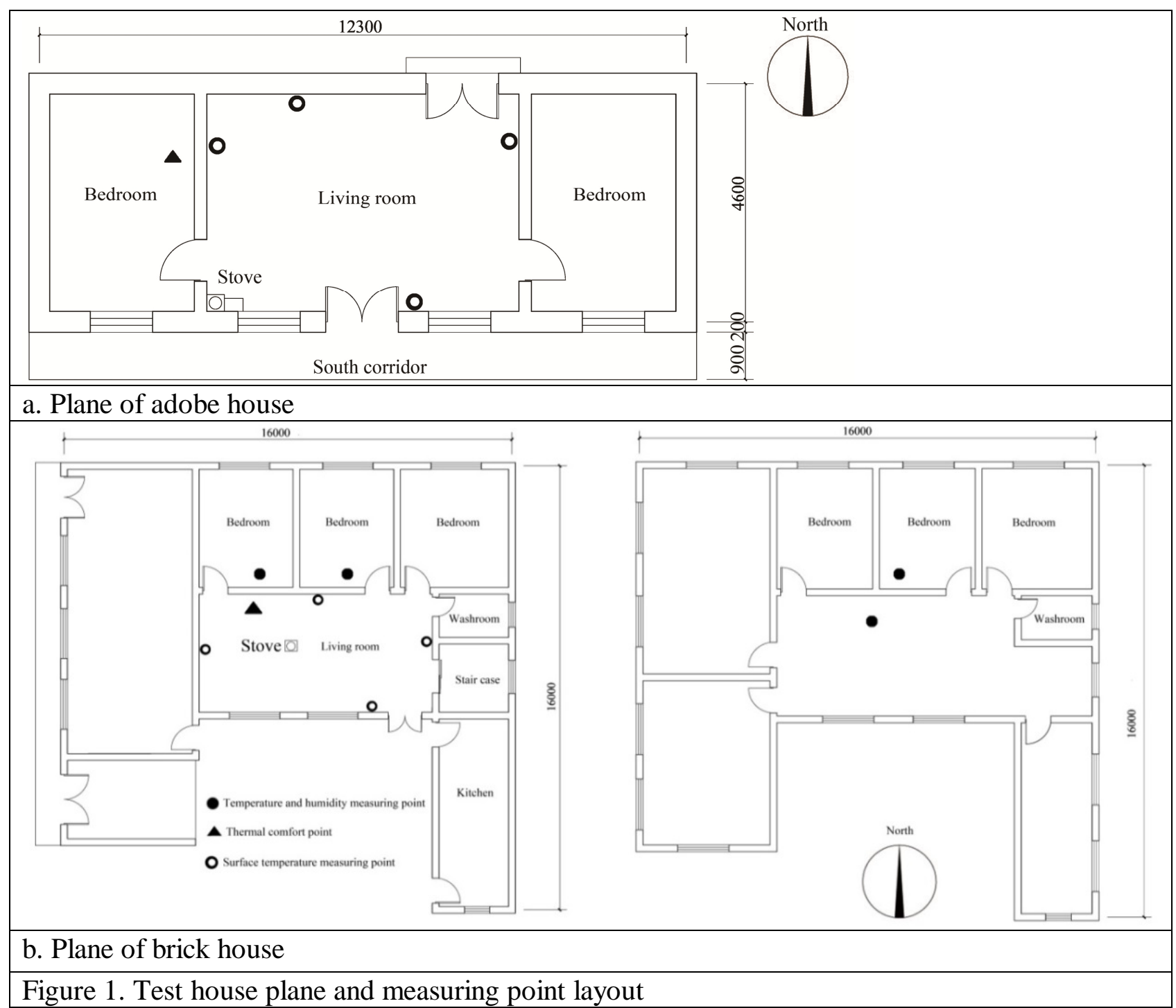

Test project. The test duration is from $3 \mathrm{pm}$ on 25 th, January to $28 \mathrm{th}$, January 2015. Test parameters include air temperature, relative humidity and wall temperature. To make the results more comparable, we select south-faced new and old residential housing, by the way, the surrounding environment and the nearby sheltering condition are also similar. Test instruments and parameters is shown in Tab. 1. Every 30 minutes, we record the test results. There is 3 consecutive days, a total of 72 hours. 
Table 1 Test instruments and parameters

\begin{tabular}{|c|c|c|c|c|c|}
\hline \multirow[t]{2}{*}{ Instrument name } & \multirow[t]{2}{*}{ Model } & \multirow[t]{2}{*}{ Test content } & \multirow[t]{2}{*}{ Test accuracy } & \multicolumn{2}{|c|}{ Sampling method } \\
\hline & & & & Mode & Interval/min \\
\hline \multirow[t]{3}{*}{$\begin{array}{c}\text { Automatic } \\
\text { weather station }\end{array}$} & PC-4 portable & $\begin{array}{c}\text { Air } \\
\text { temperature }\end{array}$ & $\pm 0.1{ }^{\circ} \mathrm{C}$ & Automatic & 30 \\
\hline & & $\begin{array}{l}\text { Relatively } \\
\text { humidity }\end{array}$ & $\pm 5 \%$ & & \\
\hline & & Radiation & $\leq 5 \%$ & & \\
\hline \multirow[t]{2}{*}{$\begin{array}{l}\text { Temperature } \\
\text { block }\end{array}$} & TR-72U & $\begin{array}{c}\text { Air } \\
\text { temperature }\end{array}$ & $\pm 0.3{ }^{\circ} \mathrm{C}$ & Automatic & 30 \\
\hline & ( Japan ) & $\begin{array}{l}\text { Relatively } \\
\text { humidity }\end{array}$ & $\pm 5 \%$ & & \\
\hline \multirow{4}{*}{$\begin{array}{c}\text { Indoor thermal } \\
\text { comfort } \\
\text { instrument }\end{array}$} & JT - IAQ & $\begin{array}{c}\text { Air } \\
\text { temperature }\end{array}$ & $\pm 0.5^{\circ} \mathrm{C}$ & Automatic & 30 \\
\hline & & $\begin{array}{l}\text { Relatively } \\
\text { humidity }\end{array}$ & $\pm 1.5 \%$ & & \\
\hline & & Air speed & $\begin{array}{l} \pm(0.03 \mathrm{~m} / \mathrm{s}+2 \% \\
\text { measured value })\end{array}$ & & \\
\hline & & $\begin{array}{l}\text { Globe } \\
\text { temperature }\end{array}$ & $\pm 0.5^{\circ} \mathrm{C}$ & & \\
\hline \multirow{2}{*}{$\begin{array}{c}\text { Surface } \\
\text { thermometer }\end{array}$} & Testo905-T2 & Surface & $\pm\left(1{ }^{\circ} \mathrm{C} \pm 1 \%\right.$ & Manual & 30 \\
\hline & & & measured value ) & & \\
\hline
\end{tabular}

\section{Analysis}

\section{Outdoor parameter analysis.}

Outdoor temperature The data of outdoor temperature is shown in Fig.2. Judging from the data, we could find though the temperature is different every day, the highest temperature appears at around $2 \mathrm{pm}$ and the lowest temperature is around $5{ }^{\circ} \mathrm{C}$ in the early morning. During the test, the outdoor temperature takes the average of $2.1^{\circ} \mathrm{C}$; the lowest temperature is at minus $1.2{ }^{\circ} \mathrm{C}$ which appears at midnight on 28th, January. The highest temperature is at $5.5^{\circ} \mathrm{C}$ which appears at noon from $12: 30 \mathrm{pm}$ to $2: 30$ pm on 26 th January.

The relative humidity. The results of outdoor relative humidity is shown in Fig.2. it shows that the outdoor relative humidity statistics fluctuates between $47 \% \sim 47 \%$, with the average of 75.8 percent. The lowest relative humidity appears at around 11:30 am on 27th January; the highest relative humidity appears at around 8 am on 26th January.

Solar radiation. We select the dwellings crowded place with no sheltering in the surrounding as our test place. It is cloudy on 25th and 27th January, and is obscured by cloud on 26th and 28th January. The recorded effective sunshine lasts about 9 hours from $8 \mathrm{am}$ to $5 \mathrm{pm}$. On January 26, the average intensity of total solar radiation is about $64 \mathrm{w} / \mathrm{m}^{2}$, the peak data is $220 \mathrm{w} / \mathrm{m}^{2}$ which appears at 12:00 at noon (shown in Fig 3). Affected by the cloud, solar radiation has bigger fluctuation during the test, but radiation patterns also lives up to Jiaozuo area in overall.North Henan belongs to the third area of solar energy resources distribution in our country. It is rich in it. From the test, we can see that the sunshine time in winter is longer, the intensity of the Solar radiation is higher, and there is no mountain near, so we can design the passive solar houses in the local dwellings and use solar energy to get heat for part of the residential houses in winter. 


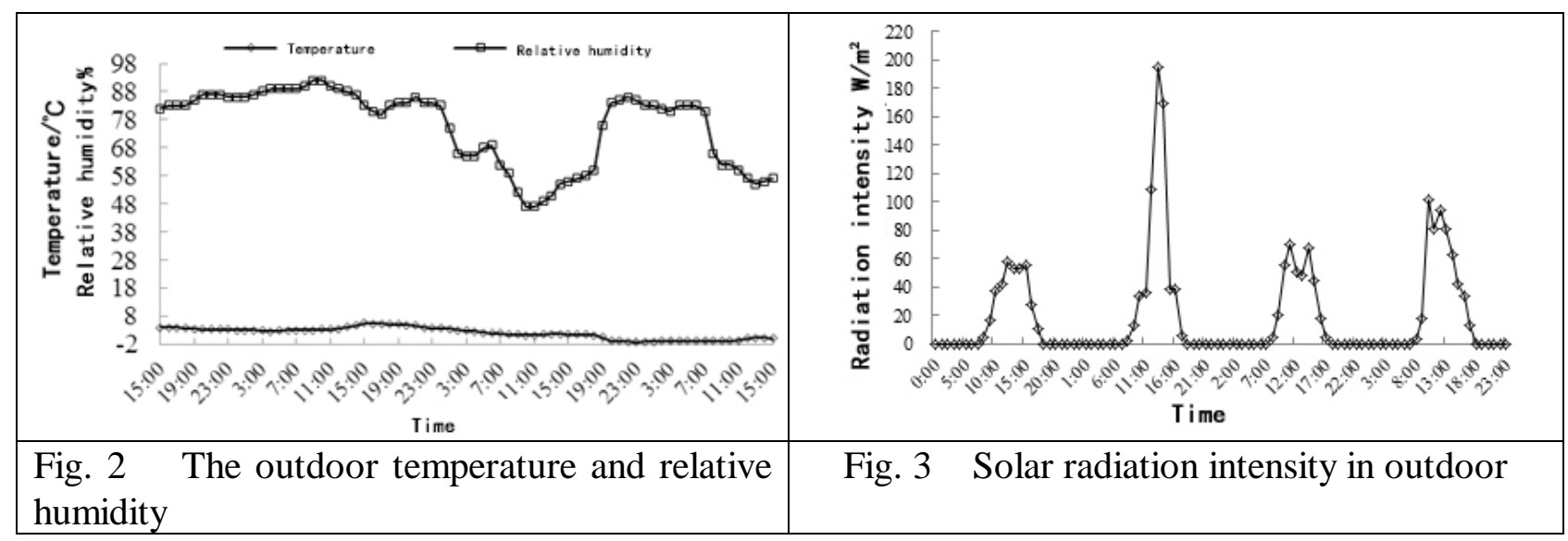

\section{Indoor parameter analysis.}

Indoor temperature. There is a coal stove inside the sitting room on the ground floor in the newly built brick houses, so the temperature is stable, significantly higher than the second floor and adobe house. With the declining of the outdoor temperature, the temperature in every room drops after time. The linear regression coefficient of different room temperature declination is respectively - 0.095 , 0.0475 and 0.0843 . It indicates that the temperature on the first floor in the brick house drops least as the outdoor temperature fluctuates. The other rooms get a larger drop (shown in Fig4). Under the condition of normal temperature and normal humidity, the coefficient of thermal conductivity in the rammed earth walls and solid clay bricks is relatively $0.72 \mathrm{~W} /\left(\mathrm{m}^{2} \cdot \mathrm{K}\right)$ and $0.81 \mathrm{~W} /\left(\mathrm{m}^{2} \mathrm{k}.\right)[1,2]$, according to the formula of thermal resistance $\mathrm{R}=\mathrm{d} / \lambda$, we could draw that the heat preservation performance of $210 \mathrm{~mm}$ rammed earth wall is equivalent to $240 \mathrm{~mm}$ thick brick wall. In fact, the rammed earth wall is $400 \mathrm{~mm}$ in adobe house. As a result, the average temperature on the second floor in the newly built brick house is significantly lower than in the adobe house. Design Specification of heating ventilating and air conditioning (GB50019-2012) [3], it shows that in cold areas, the comfortable indoor temperature in winter is for $18{ }^{\circ} \mathrm{C} \sim 24^{\circ} \mathrm{C}$. According to test data, the temperature in the newly built brick house and adobe house is lower than it in specification.

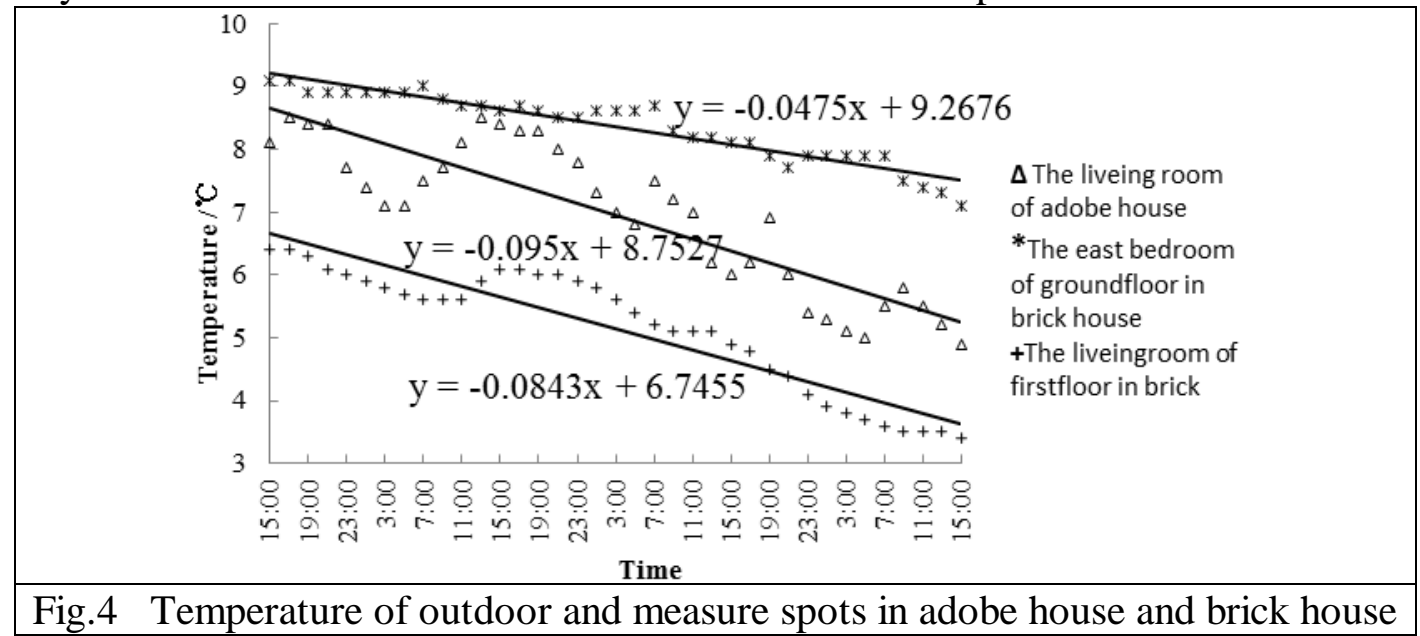

Relative humidity. Using the common moving average of the analysis in the stock market changes, we select the first floor and the second floor in outdoor, adobe house and brick house. It directly shows every rooms relative humidity changing trend (shown in Fig5) China development research report on building energy conservation [4] mentioned that the comfortable relative humidity indoor in winter is $30 \% \sim 70 \%$, the relative humidity in brick houses comply with this requirement, but it in adobe house is slightly higher than that of the standard, and this result is in line with the other scholar research[2,5] The reason is that the vapor permeability of rammed earth wall is greater than solid clay brick. Under the same condition of the humidity, the balance amount of moisture absorption in rammed earth wall is greater than solid clay brick. In winter, we should appropriately reduce indoor humidity to build indoor comfort. 


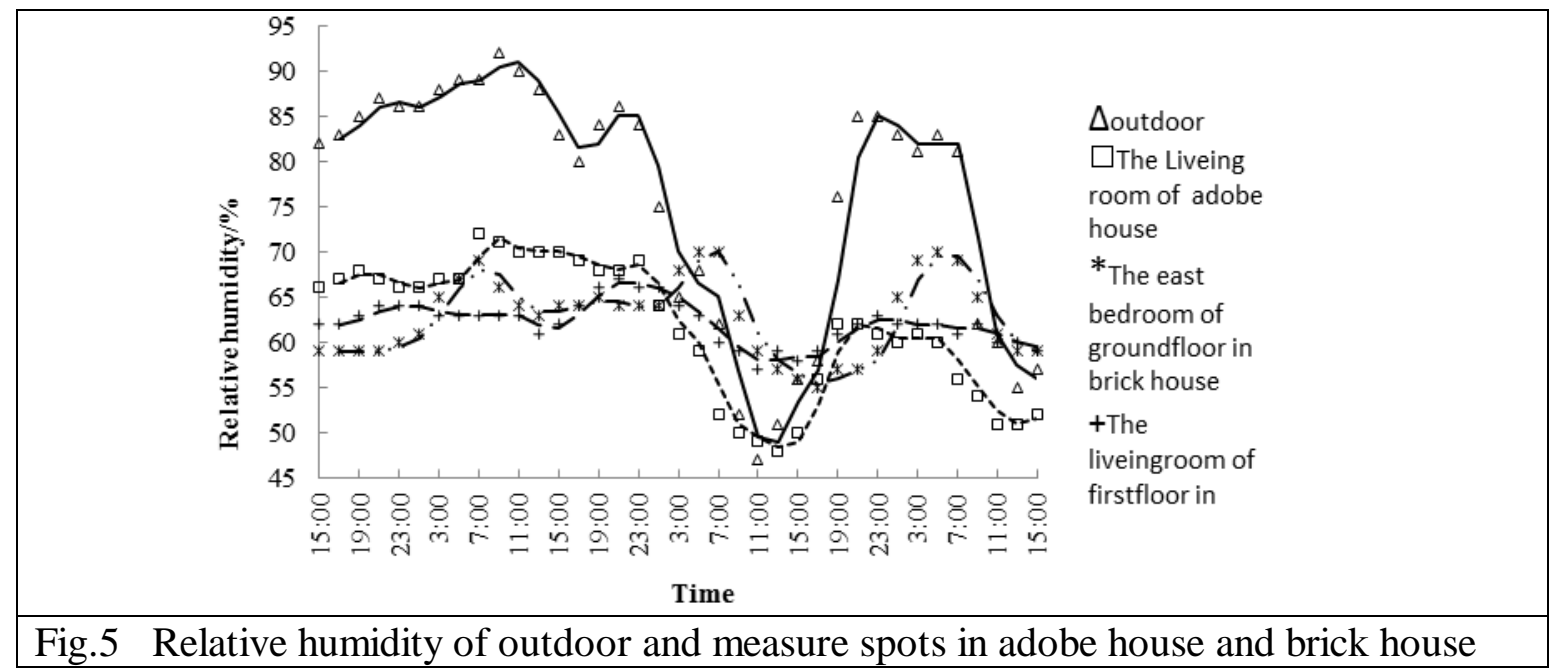

The wall temperature.Using the surface thermometer, the temperature test on every wall in sitting room in adobe house and brick house shows the wall temperature is lower in adobe house, and temperatures in four walls are close. The wall temperature in east and west walls adjacent to the living room is a bit higher. The north wall temperature is the lowest, because it doesn't get sunshine or isn't adjacent to any other rooms. Due to the larger thermal resistance of exterior wall materials, wall temperature is relatively delayed than outdoor temperature, and fluctuates slightly. (shown in Fig 6a).

Generally speaking, the wall temperature in the newly built brick house is higher than in adobe house. Compared with every wall temperature, we could find that the ground temperature is significantly higher than the other walls and the roof temperature. So the ground foundation and heat preservation effect is great in the newly built brick house. Other walls are adjacent to living room or other rooms, therefore, the temperature is higher than that of the roof. The wall faces south changes significantly if the outdoor temperature changes. (shown in Fig 6b).

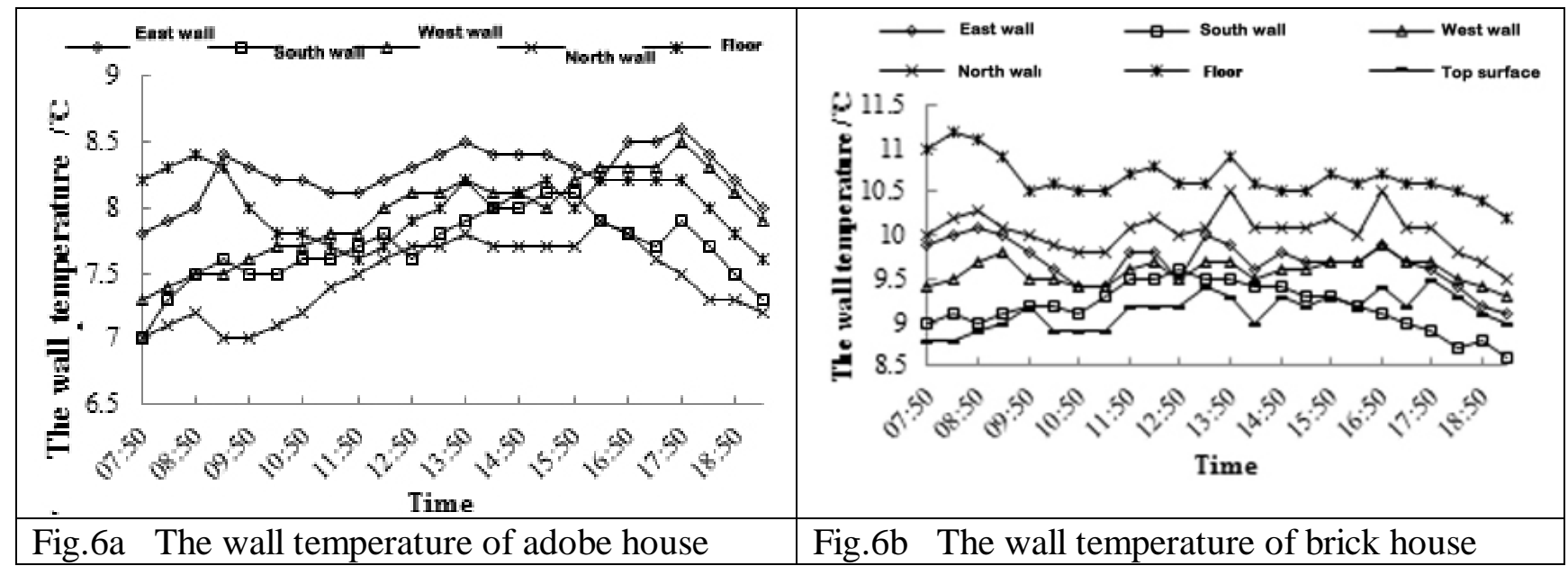

Mean radiant temperature. (MRT) Mean radiant temperature has great influence on human body of hot and cold feeling. It is one of the important factors affecting the winter indoor thermal comfort[6,7]. Inside the room, if the difference between wall temperature and air temperature is big, the influence of thermal radiation is big too.[8]The indoor thermal comfort instrument used in this test can calculate the average radiation temperature by the indoor air temperature, wind speed and black ball temperature. The indoor air temperature and MRT in adobe house and in brick house is shown in Fig 7. From the picture, the indoor temperature has the same change trend with MRT, that is to say, the indoor air temperature is affected by the MRT is bigger than outdoor air temperature. The conclusion is the same with the literature[9]. The west side of the bedroom in adobe house has the average MRT of $7.84{ }^{\circ} \mathrm{C}$, with the average air temperature is $8.2{ }^{\circ} \mathrm{C}$. It doesn't differ much. The air temperature is slightly higher than the average radiation temperature of $0.362{ }^{\circ} \mathrm{C}$. On average, MRT in the sitting room in brick house is $8.59{ }^{\circ} \mathrm{C}$, the air temperature is $9.48{ }^{\circ} \mathrm{C}$, higher than the average radiation 
temperature of $0.89^{\circ} \mathrm{C}$. Therefore, MRT has smaller influence on the indoor thermal comfort both in adobe house and in brick house.

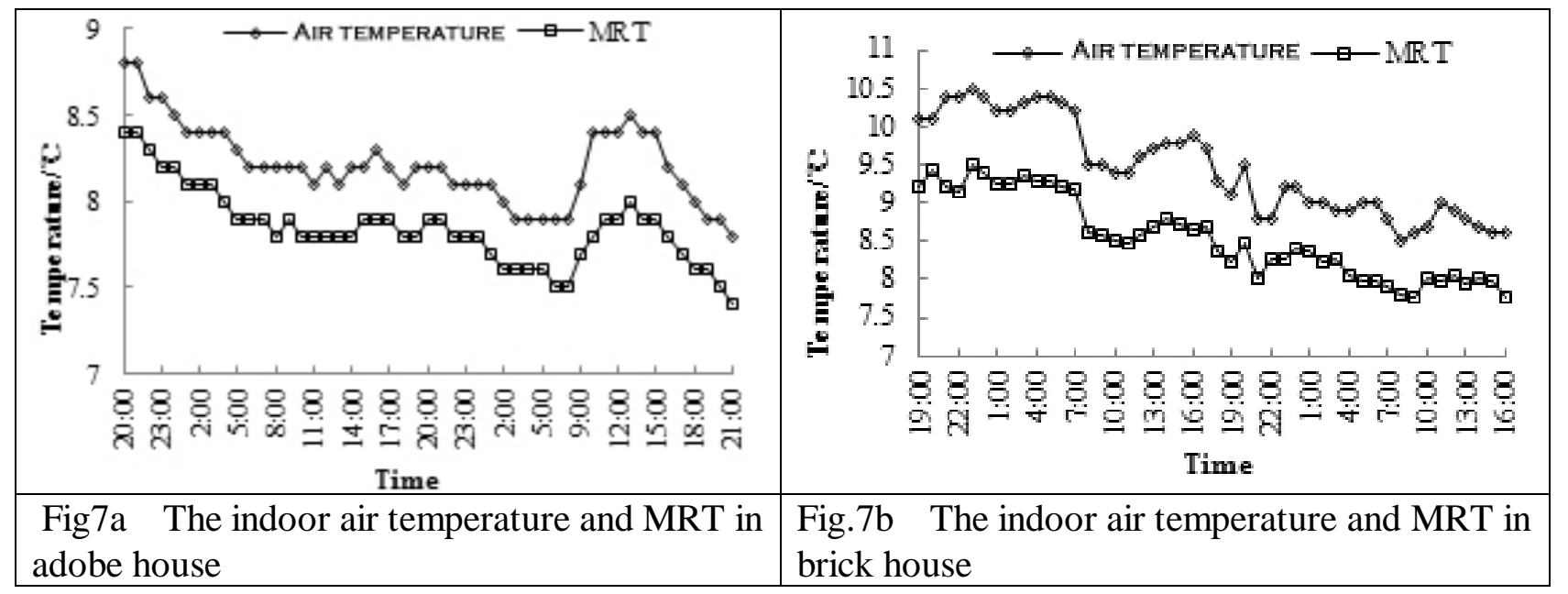

\section{Conclusions}

Judging from the test results, the room temperature of both the new and old residences is lower than the local thermal environment index for residential buildings [10], which is mainly caused by the reason of the high humidity of the adobe indoor room [2]. Special geographical and climatic characteristics of the Northern part of Henan Province lead to the requirements for the design of buildings considering climate adaptability, which include the cold-proof and insulation for the winter cold, and the heat-protection for the summer heat, especially for the resistance of the west sunshine to the main room [11]. According to the test result and field research, this paper puts forward the following suggestions for improvement:

The indoor layout of the newly built house of bricks mixed is more rational, but it is better to try to reduce envelope area, enhance both the closeness and the ventilation in winter as well as the use of solar and other energy-saving measures. In the new residences, single-layer heat transfer coefficient for aluminium window $6.4 \mathrm{~W} /($ square $\cdot \mathrm{K}$ ), that is, heat loss per unit area is 3 times more than the wall. If using plastic frames, double-pane, heat transfer coefficient can be reduced to $2.6 \mathrm{~W} /(\mathrm{m} 2 \cdot \mathrm{K})[12]$. Moreover, people can build the wall insulation and reduce the heat loss of the envelope structure to improve the indoor air temperature, as well as the indoor thermal environmental condition.

The thick walls of the adobe dwellings have good insulating properties, but take up too much space. Poorly sealed doors and windows and the local habits of main room's door openness lead to the overly lowness of the room temperature. In addition, the study has showed that ground insulation is particularly important. People should take measures to strengthen the insulation of the ground within $2 \mathrm{~m}$ inside the outer walls. To achieve the improvement of the indoor thermal environment, following measures are suggested to be taken: using window insulation film, filling with thermal insulation mortar between the window frame and the wall, strengthening thermal bridges thermal insulation, reducing the heat loss form the window and setting the sun room at the entrance.

Due to the base without any moisture-proof handle for the adobe dwellings, outdoor moisture can easily go into the room through the base, which leads to the high relative humidity for the indoor air. Combined with the lower surface temperature, it is prone to form the condensation on the surface. Accordingly, doing the moisture-proof handle in the base and the lower part of the wall, and enhancing the room's closeness, which can reduce indoor humidity, are important ways and measures for improving the Adobe dwellings' indoor air temperature and the indoor thermal comfort. 


\section{Acknowledgements}

The work is supported by National Natural Science Foundation of China (Project No. 51408198), and the China postdoctoral Science Foundation (2015M570818). The authors are grateful to the occupants for allowing this study to be conducted in their living quarters. The authors would also thank their students for their help with the data gathering and analysis.

\section{References}

[1]China Building Science Research Institute. 2012. GB50176-2012 Code for thermal design of civil buildings. Beijing: China Planning Press.1993. "In Chinese"

[2]Yan Z. 2003. Adobe building indoor thermal environment research. Ph.D. Thesis, Xi'an University of Architecture and Technology, 132 pages. "In Chinese"

[3]ChinaAcademyofBuildingResearch Code for design of heating ventilation and air conditioning. [S]GB50019-2012. Beijing: China building industry press, 2012."In Chinese"

[4]Building energy research center of Tsinghua university. Annual report on China building energy efficiency development [M]. Beijing: China Building Industry Press, 2011. "In Chinese"

[5]Liu D., Liu J., He Q., et al. Journal of Xi'an University of Architecture and Technology (Natural Science Edition), 42(1), pp: 83-86. "In Chinese"

[6]GeFenghua, Liu Xunjun,WangChunqing. radiant cooling, 2006, 23(2): 45-48. "In Chinese"

[7]Mohammad S. Al-Homoud, Adel A. Abdou, Ismail M. Budaiwi. Energy and Buildings 2009,41(11):607-614.

[8]Liu Jiaping, Yang Liu. Study on indoor thermal environment [M]. Beijing: China Building Industry Press. 2005. "In Chinese"

[9]Jiaping Liu, Lijuan Wang, Yasuko Yoshino, etc. Building and Environment 2011, 46 (2): 1709-1715.

[10]Yan Haiyan, Yang Liu,ZhouShubin. Heating Ventilating and Air conditioning; 2011, 41(11): 119-125. "In Chinese"

[11]Yang Liu. Bioclimatic architecture. [M]. Beijing: China building industry press, 2010. "In Chinese"

[12]Liu Xiaotu.Building physics[M]. Beijing: China building industry press, 2010. "In Chinese" 